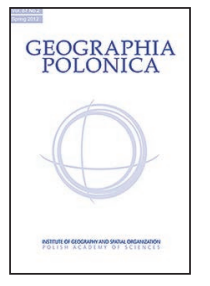

\title{
SOCIAL RESPONSE AND SPATIAL MOBILITY CHANGE DUE TO COVID-19 PANDEMIC IN POLAND
}

\section{Joanna Stępień ${ }^{1}$ (D) - Tomasz Michalski ${ }^{2}$ (D) Jakub Grabowski ${ }^{3}$ (D) Przemysław Waszak $^{4}$ (D) Maja Grabkowska ${ }^{1}$ (D) Aleksandra Macul ${ }^{5}$ (D) Jakub Jan Rojek ${ }^{5}$ (D)}

${ }^{1}$ Department of Socio-Economic Geography, Institute of Geography

University of Gdańsk

Bażyńskiego 4, 80-952 Gdańsk: Poland

e-mails: joanna.stepien@ug.edu.pl•

maja.grabkowska@ug.edu.pl

${ }^{2}$ Department of Regional Development, Institute of Geography

University of Gdańsk

Bażyńskiego 4, 80-952 Gdańsk: Poland

e-mail: tomasz.michalski@ug.edu.pl

${ }^{3}$ Department of Developmental Psychiatry,

Psychotic and Geriatric Disorders

Medical University of Gdańsk

Skłodowskiej-Curie 3a, 80-210 Gdańsk: Poland

e-mail: jakub.grabowski@gumed.edu.pl
${ }^{4}$ Department of Hygiene \& Epidemiology, Department of Developmental Psychiatry, Psychotic and Geriatric Disorders Medical University of Gdańsk Skłodowskiej-Curie 3a, 80-210 Gdańsk: Poland e-mail: p.waszak@gumed.edu.pl

${ }^{5}$ Adult Psychiatry Scientific Circle, Department of Developmental Psychiatry, Psychotic and Geriatric Disorders Medical University of Gdańsk

Skłodowskiej-Curie 3a, 80-210 Gdańsk: Poland e-mails: aleksandramacul@gumed.edu.pl • jakubjanrojek@gumed.edu.pl

\begin{abstract}
As global communities respond to the COVID-19 pandemic, there has been an increasing emphasis on public health strategies, like implementation of 'lockdowns', closure of educational institutions and offices, cancellation of events, and enforcement of social distancing measures to slow the rate of transmission. The main objective of this article is to find out how the public health interventions and national lockdown affected people's perception and attitudes to limited mobility and how people reacted by their spatial mobility behaviours in new reality of the first weeks of COVID-19 pandemic in Poland. The study is based on the on-line survey research conducted among Polish residents supplemented by the analysis of data on changes in the spatial mobility based on Google dataset. The obtained results highlight high level of self-discipline in the population in response to restrictions and social distancing obligations, and as a result significantly lower spatial mobility level, before the restrictions began to be lifted. The size of the respondents' place of residence had the greatest impact on changes in spatial mobility.
\end{abstract}

\section{Key words}

social response $\cdot$ spatial mobility change $\cdot$ COVID-19 pandemic $・$ Poland 


\section{Introduction}

Epidemics and pandemics have been accompanying human beings from the very beginning (Hays, 2005; Ruffié \& Sournia, 1999). Historically, people considered epidemics to be part of their lives, creating health and cultural behaviours that would allow them to survive, while accepting the inevitability of death (Sznajderman, 1994). Advances in medicine have led modern man to believe that the time of the epidemic is over. By the end of the 1970s, there was a growing conviction that victory over infectious diseases was imminent. But the advent of the HIV/AIDS pandemic has destroyed this complacency (Nuland, 1993). Observation of the emergence and development of COVID-19 pandemic, confirms Bernard's (1993) prediction that the HIV/AIDS pandemic would either be overcome or end by itself, but another epidemic would emerge decades after the previous one.

Focusing on the social, economic and political consequences of a pandemic, one may state that very often it causes major breakthrough changes in the history of the world or region. For example, Meier (2016) notes the fundamental significance of the Justinianic Plague (541-542, recurrences up to c. 750) to the transformation of the eastern Roman into the Byzantine empire 1 . On the other hand, Welford (2018) emphasizes the role of the primary wave of the Black Death (1347-1353) in the collapse of the Mediterranean region as a political, economic and social power and its replacement by England and the Netherlands. In turn, the smallpox epidemic (1520), brought to Mexico by the Spanish conquistadors - facilitated their conquests in Central Mexico (McCaa, 1995). Past pandemics also negatively impacted the mental health of the population (Honigsbaum, 2013), and the COVID-19 pandemic is no different (Luo et al., 2020).

\footnotetext{
1 However, Mordechai et al. (2019) believe that the role of the Justinianic Plague in these civilization changes is exaggerated.
}

Officially the COVID-19 epidemic started in December 2019 in Wuhan, China (Huang et al., 2020), and on the 11th of March 2020, $\mathrm{WHO}$ announced that we were dealing with a pandemic (WHO Director..., 2020). In Poland, the first case of SARS-CoV-2 (novel coronavirus) infection was recorded on March 4, 2020. According to the official statistics of new infections, in comparison with Western European countries, the pandemic developed in Poland rather slowly at first. In the first two months of its duration (until April 30, 2020), only 12,877 infections and 644 deaths were recorded (Raciborski et al., 2020). This may have been partly due to the early introduction of strict public health interventions (lockdown) in Poland (Fig.1), although it should be mentioned that the number of coronavirus tests performed per 1 million inhabitants placed Poland at that time below the European average (during April-May 2020 between 0.29-0.51 per $1 \mathrm{mln}$ inhabitants, comparing for example to 1.07-1.46 in UK) and the official statistics may not have reflected then fully the scale of health situation.

The main objective of this article is to analyse how the public health interventions and introduction of national lockdown affected people's attitudes and behaviours to limited mobility and how they corresponded with spatial mobility change of population in new reality of the first weeks of COVID-19 pandemic in Poland. Spatial mobility is understood here not only as transportation patterns but also as everyday spatial behaviours, such as shopping, walking or spending time in public spaces (parks, squares, beaches or any other places open to the public).

In relation to the main objective we put three research questions:

1. How people reacted to restrictions and responded with their everyday spatial mobility behaviours?

2. How their behaviours differed depending on selected socio-demographic characteristics?

3. Whether there were any significant differences in spatial behaviours depending on the size of the place of residence? 

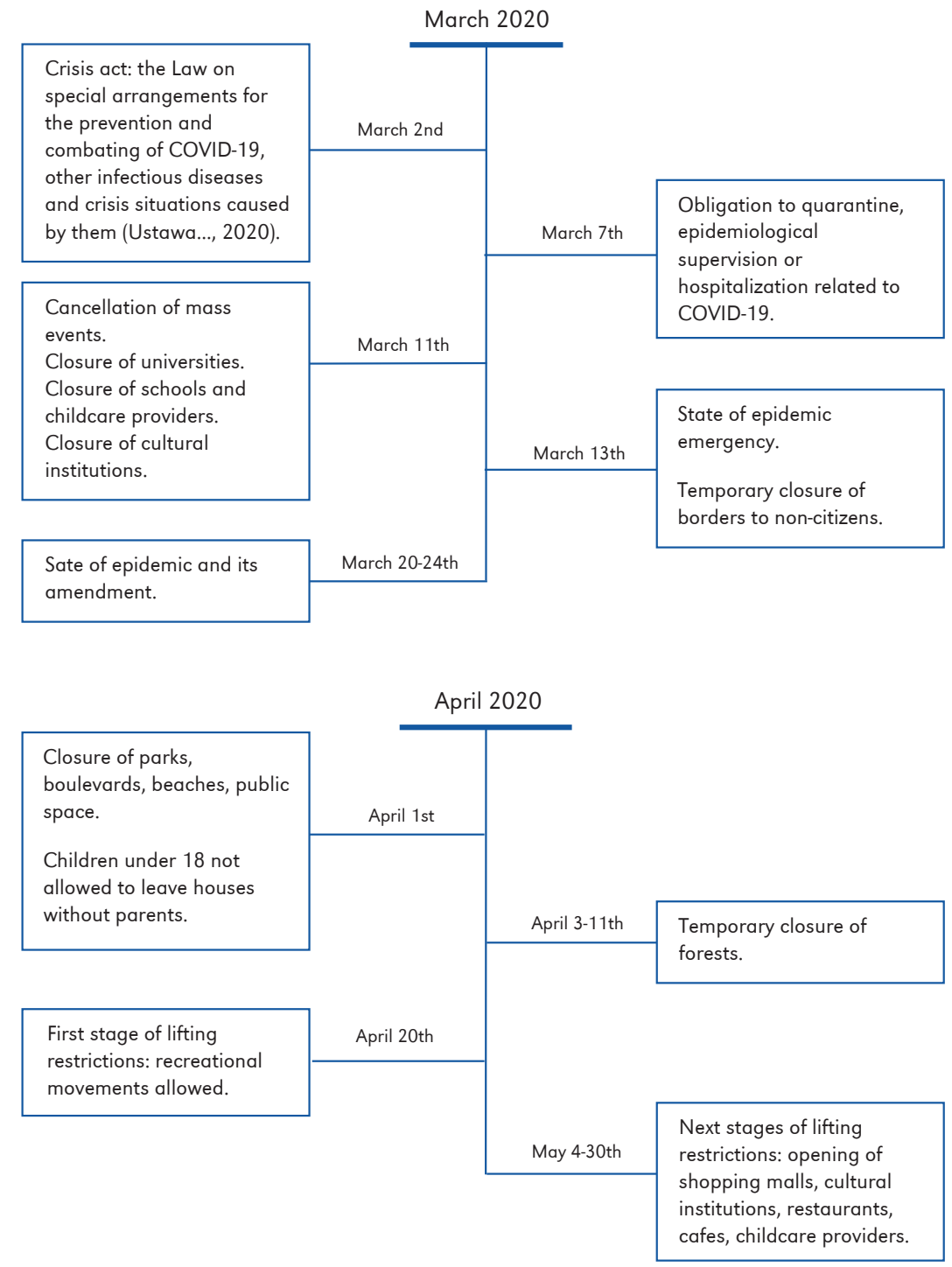

Figure 1. Public health interventions between March and May 2020 to mitigate the early spread of SARS-CoV-2 in Poland

Source: own elaboration based on Pinkas et al. (2020) and Medicover (2020).

The analyses are based on a quantitative survey research on the perception of social isolation/distancing, carried out using an online survey among the inhabitants of Poland (more details in the Methodology section), covering all regions of the country. The results of the survey are supplemented with the quantitative analysis of data on changes in the spatial mobility patterns in Poland during the COVID-19 pandemic, gathered by Google and publicly released in the form of open data.

The structure of the article starts with a short review of literature on relation 
between spread of infectious diseases and human spatial mobility. This part is followed by methodology section clarifying the sources of data and computational procedures. The following section discusses in details the results of the research analysis, indicating significant changes in spatial mobility and their possible reasons. Next the article proceeds with a discussion summarising implications on population's response to interventions during health crisis such as pandemics, in particular with relation to spatial behaviours, and ends with conclusion.

\section{Literature review}

Reducing human spatial mobility may be an effective way of limiting the spread of infectious diseases. However, there is a lack of broad knowledge about the optimal scope of the introduced public interventions on spatial mobility and their impact on public health, as well as the negative effects on the freedom of movement, economy and society (Zhou et al., 2020).

As Tarkowski et al. (2020) notice, most studies are devoted to two main aspects: (1) the development of infectious diseases and spatial mobility of people focus on the problem of spreading pathogens by spatial interactions between people, as well as (2) the economic effects of limited mobility on the transport sector.

Several studies indicate a link between public interventions, especially national lockdowns, with the general positive impact on the changes in number of new infections. They point out that the more severe restrictions, the higher decrease in spatial mobility which rapidly reduces transmission below the levels necessary to overcome the epidemic, particularly in relation to highly contagious disease as COVID-19 (Ciancio et al., 2020). On the other hand many dependencies resulting from the introduced restrictions and lockdowns are unexplored in necessary details to give precise explanation whether the scope and duration of the restrictions are optimal (Aloi et al., 2020) and how effective are institutional interventions and behaviours, including spatial mobility, undertaken by people in response to restrictions (Arimura et al., 2020; Drake et al., 2020).

Another unknown problem is whether lockdown, despite its short-term positive impact, is a sustainable solution to control the spread of infectious diseases in the long run. This strategy may give the governments a window of opportunity to accelerate its health infrastructure and personnel and prepare necessary response to epidemic (Sabat et al., 2020). On the contrary, several studies question the lockdown measures particularly for their damaging economic and social effects, in particular the harsh impact on the economically disadvantaged people (Yadav \& Bhattacharjee, 2020).

In the context of the research objective undertaken in this study, one of the key issue to examine is the social response to restrictions and limitations in spatial mobility - whether people follow the introduced interventions or break the prohibition of movement in public space. Social distancing practices can limit the severity of an epidemic, but the positive effects of social distancing depend on the extent to which it is followed by people (Engle et al., 2020; Nguyen et al., 2020; Kaplan et al., 2020). They are to some extent reluctant to bear the costs intrinsic in social distancing, but this factor can also limit its effectiveness. People are likely to take restrictive measures only when there is a particular encouragement to do so (Reluga, 2010), for example when they believe in the effectiveness of protective effects (Meier et al., 2020).

\section{Methodology}

At the turn of March/April 2020 as a result of the emergence of coronavirus cases in Poland and the gradual introduction of restrictions related to the struggle against the epidemic, almost the entire society found itself in a situation of necessary social distancing. This situation was a motivator to examine how people cope as a society with the new reality, whether they accept 
the restrictions, and how their spatial behaviours have changed as a result of following the recommendations. The on-line social survey was conducted in the first weeks (April-May 2020) after the first cases of COVID-19 were diagnosed in Poland, and while the restrictions in movement and other sanitary requirements in the country increased. We decided to extend the study in time until mid-May, as in the meantime two events took place (Easter holiday and the long weekend at the beginning of May), which usually significantly reduce the interest in participating in surveys. Moreover, during this period the governmental restrictions were changed several times, having an impact on population response.

Due to the nationwide lockdown during the examined period, it was challenging to perform a community sampling and a face-to-face survey, so we adopted an online tool to collect the data. The survey was carried out using an on-line questionnaire to be completed by the respondent. Participation in the study was entirely voluntary. The links to questionnaire were posted on thematic portals of national and regional media, as well as on websites of individual regions and provincial cities and through social media. This was to ensure the participation of residents from all regions in the country. Similar on-line surveys were used to study people's reactions to COVID-19, among others by Huang \& Zhao (2020), MoghanibashiMansourieh (2020) and Ozamiz-Etxebarria et al. (2020).

Respondents who participated in the study were asked to refer to several issues, such as: general assessment of their health condition, feelings and general state of mind in the last month before participation in the study, opinions on the institutional interventions and social isolation, spatial behaviours during isolation, the use of modern technologies during this period, the assessment of support during the epidemic, and concerns about the future. For the purposes of this study we focused in our analysis on the aspect of spatial mobility and spatial behaviours mainly, as well as selected socio-economic variables.
Altogether 6169 respondents took part in the study, which should be considered as a large sample. Nevertheless, due to the remote survey method adopted, one should be careful with the results and their representativeness. For this reason descriptive analysis with measures of frequency are used to present perception, attitudes and behaviours among study participants. We elaborated frequency distribution tables for the selected independent and dependent variables, as well as correlation statistics for mobility patterns.

The basic socio-economic characteristics of the study are as follow: men constituted $23 \%$ of the respondents, $76 \%$ - were women, while $1 \%$ of the respondents refused to indicate their gender. In terms of age, 32\% of the respondents represented the youngest age group (18-24 years old), 33\% the 25-34 age group, $29 \%$ of the participants were $35-54$ years old, and nearly $6 \%$ over 55 years old. In terms of the place of residence, $36 \%$ of the respondents came from large cities with more than 500 thousand inhabitants, $31 \%$ of participants represent cities with a size between 150 to 500 thousand people, 10\% lived in the city between 50 to 150 thousand inhabitants, and $12 \%$ came from the smallest towns up to 50 thousand people, the remaining $11 \%$ lived in the countryside.

As the aspects related to the size of residential place of respondents were the crucial criterion (alongside such factors as age, education and economic situation) for the study results' analysis as probable factor that differentiate spatial behaviours (compare with Agüero et al., 2011), we used the scale of residence size that would be most convenient for respondents to indicate. Before starting the survey design, two variants of the description of the respondents' origins were considered: spatial and non-spatial. In the first, the respondents would indicate the region they come from. Regionalization was considered based on an administrative or historical-cultural criterion (Grad, 2010; Kulesza, 2014). This approach was abandoned because it was decided that voivodships are too 
large units, and the respondents could fear of indications based on poviats or communes. It is related to concerns about the privacy of respondents, particularly in on-line surveys (Huang, 2006; Siuda, 2010). In the case of cultural regions, it was found that they are not strictly delimited in social consciousness, and the requirement for indications based on communes or poviats (which would then be assigned to specific ethnic, historical regions, etc.) respondents might have been afraid.

In the case of the non-spatial approach, the best seemed to be based on the concept of the urban-rural continuum (Falkowski \& Brodowski, 2008; Bański, 2009; Siemiński, 2010) or on the concept of functional urban areas (Śleszyński, 2013; 2015; 2016). However, since some of the respondents would find it difficult to indicate a specific category, they should again point the address of their stay with the accuracy of the poviat or commune. And, as already signaled, they might be afraid of their privacy. Therefore, it remained to rely only on the size criterion for indicating the residential place by respondents.

\section{Strengths and limitations}

The major strength of this study lies in its large sample size recruited in the critical phase of COVID-19 pandemic outbreak in Poland. Capturing the critical moment in the development of the pandemic gives us the possibility for comparisons with surveys and interviews carried out in subsequent phases. We are aware that this study has also several limitations. First, in order avoid possible infections, we used a web-based survey instead of the traditional, face-to-face one. As a result, the sampling of our study was voluntary and thus uncontrollable. Therefore, the possibility of a selection bias should be considered. Secondly, due to the sudden occurrence of the disease, we were unable to assess the individuals' physiological and psychological conditions before the outbreak. Only the next round of research, especially through the use of qualitative methods, will present a clearer picture of the actual changes in the public perception of the epidemic and the accompanying restrictions.

\section{Restrictions' recognition and obligation to social distancing perception}

The results of the survey show that during first weeks of pandemic and public health interventions introduced in Poland social distancing was widely recognized by the respondents (in total about 90\%, while definitely agree $52 \%$ ) as an effective way to limit the spread of infectious diseases. Similarly, a large group of respondents agreed that it is necessary to submit to mandatory quarantine, if one is imposed on someone, and those who do not comply with it should be punished and forcibly isolated, although there were even more strong opinions (in total $88 \%$, while definitely agree more than 60\%). There was a widespread belief that people undergoing quarantine protect their immediate surroundings (in total 90\%), and the respondents were slightly less unanimous as to protecting their families from infection (in total 77\%) (Fig.2).

Opinions on exigence of restrictions and isolation were very similar, regardless of the gender and financial situation. There were some differences in terms of firm opinions among the inhabitants depending on the size of the place of residence. Rural residents as well as inhabitants from biggest cities slightly more often agreed with the definitive claims that social distancing effectively protects against the increase in the number of infections, as well as the right to introduce restrictions and limitation by public institutions responsible for protecting the population' health, if there is a basis for it. Respondents living in smaller towns and medium-sized cities expressed less firm opinions on the necessity to introduce restrictions or the legitimacy of social distancing measure.

The vast majority of the respondents (in total over 90\%) agreed that everyone should be informed about the reasons for the restrictions in social contacts and the purpose 


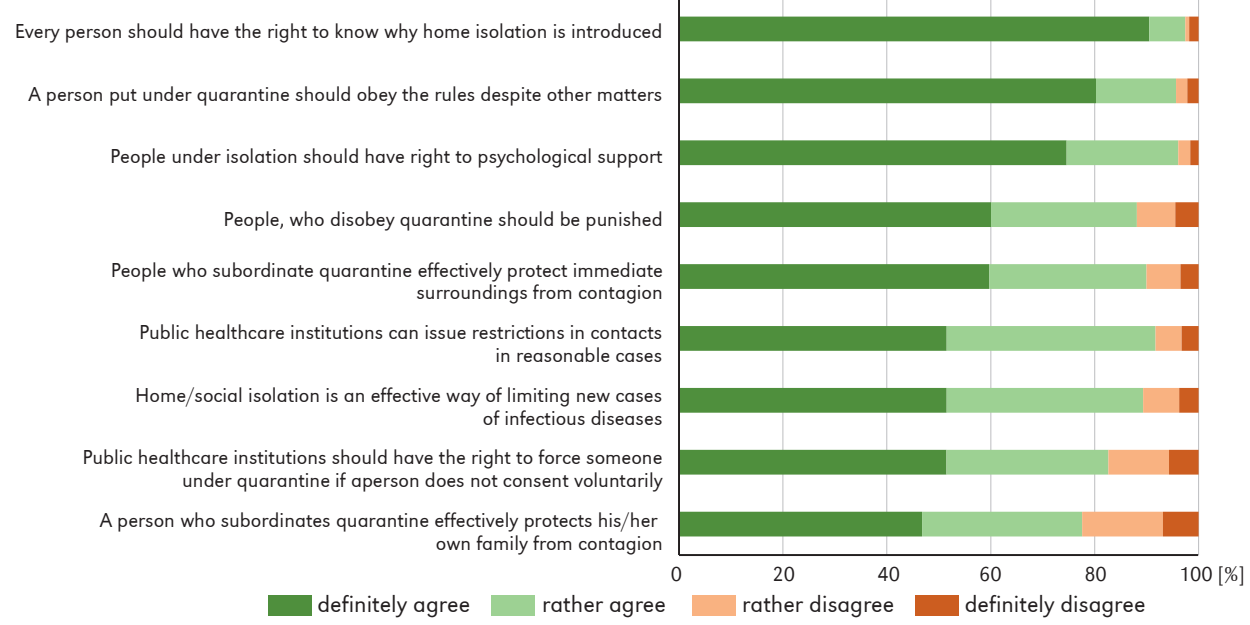

Figure 2. Perception of restrictions and exigency of social isolation

of isolating one selves from each other in the event of an infectious disease. At the same time, there was widespread agreement that institutions responsible for protecting the public health had the right to limit social contacts in justified situations, although there were clearly fewer strong opinions (in total $82 \%$, while definitely agree slightly over $50 \%$ ).

\section{Spatial mobility behaviours during obligatory social distancing and national lockdown}

In relation to the actual spatial behaviours the results of the survey indicate high social self-discipline and compliance with the introduced restrictions in the first weeks after the announcement of the COVID-19 epidemic in Poland. The vast majority of people left home only for the most necessary things, including shopping (in total nearly $88 \%$ ). Some of the respondents (slightly over 40\%) went out for a walk, but only in the immediate vicinity of their place of residence, also because of children or having an animal (about 26\%), much less people practiced sports (around $12 \%)$. Spending time in public spaces was indicated only by $6 \%$ of respondents, and meeting with friends on regular basis by $4 \%$. Attending places of religious worship refers to less than 3\% participants. Only slightly more than $30 \%$ of people left home to work, which is partly the result of switching to the remote mode of work in many companies. While this aspect did not apply to more than $40 \%$ of respondents, this group included both unemployed people and students, but also women on maternity leave and people whose work was temporarily suspended due to the epidemic or who lost their job (Fig.3).

It is worth adding here that remote work was confirmed in the study by over $60 \%$ of professionally active respondents, which was important in limiting spatial mobility. For these people, modern information and communication technologies were primarily used to fulfil their official duties and work. For students, technologies provided the possibility of completing compulsory education (half of the respondents), while some of them worked simultaneously (mainly university students). For most of the respondents, however, technologies were mainly used to communicate with family and friends and as one of the forms of spending free time (e.g. watching movies, series, concerts and online performances). They were also an important source of information, including on the epidemic, ways of spreading the coronavirus or preventive measures. 


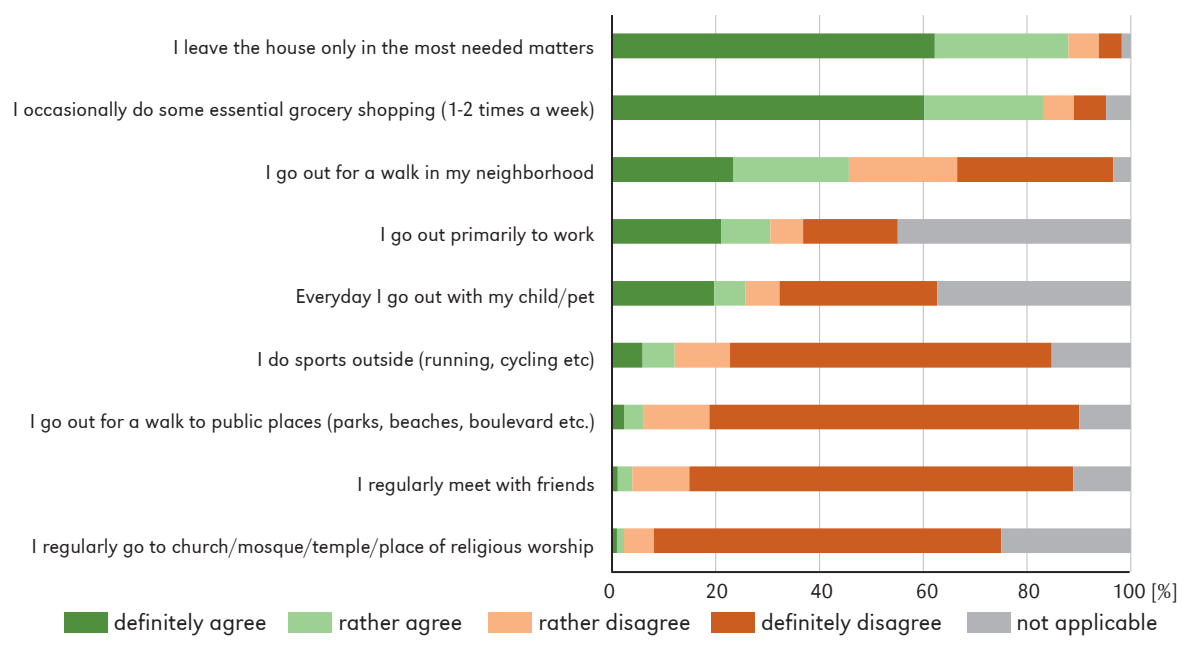

Figure 3. Spatial behaviours' change during national lockdown

In the case of spatial behaviour, there were clear differences in terms of gender - women more often left the apartment to do shopping and arrange the most necessary matters (firm statements - 62\% to 53\%), while men did so more often due to their work (in total $37 \%$ to $28 \%$ ), as well as to play sports (in total $17 \%$ to $10 \%)$. Age also significantly differentiated the spatial behaviour of the respondents, but these differences resulted mainly from the type of professional activity of the respondents or the lack of it, despite a significant percentage of people who switched to remote work. The differences were also noticeable in the case of practicing sports outside the home, where younger age groups were more often active. In the case of visits to the church, what is worth noting is that the dominant age group was 55-64, and not the oldest one ( $>75$ years old).

In terms of education, the higher the level of education, the more often the respondents left their homes only in the most necessary matters and did shopping occasionally. Also, less often than respondents with vocational education, the highly educated left their place of residence for professional purposes. The lower the level of education, the more often the respondents admitted to meeting friends, although in general these were still sporadic cases. The better their financial situation, the less frequently the respondents left their apartments for professional purposes, they did shopping occasionally and more often they left the apartment only in the most necessary matters. These indications closely correspond with behaviours conditioned by the level of education. In other aspects, the financial situation did not clearly differentiate the respondents' indications.

The spatial behaviours were analysed in more details in relation to the place of residence, as there were some significant differences in the responses of the participants. Table 1 presents the correlations between the size of the residential place as explanatory variable and selected explained variables related to spatial behaviours and mobility of respondents. Based on the frequency distribution tables and correlation coefficients the larger the place of residence, the more limited spatial behaviours of respondents, with some exceptions.

Inhabitants of rural areas clearly more often indicated walking in the vicinity of their place of residence, also due to having children or pets, and practicing sports outside their home. Respondents living in town up to 50 thousand people were slightly more active in terms of practising sport outside 
home. City dwellers from cities with population between 50 and 150 thousand and in larger cities between 150 and 500 thousand people were more likely to leave home in connection with their professional work, and also went to church slightly more frequently. Inhabitants of the largest cities (over 500 thousand people) more often indicated occasional purchases and leaving homes only for the most needed cases. In other matters, opinions were similar regardless of the size of the place of residence (Tab.1).

High levels of discipline and adaptation to social mobility restrictions in Poland indicated by the survey are confirmed by the quantitative data on spatial mobility (compare also with results from similar study by Santamaria et al., 2020), which have been gathered by Google since February 2020 and presented in its COVID-19 Community Mobility Reports. In the end of March, Google publicly released mobility data aggregated from mobile device location information. These data can be used to identify the locations visited by individuals, making it possible to compare their pre-restriction (baseline) to post-restriction activity. As the Google Android operating system has the largest market share, these data are likely to capture the movements of more individuals than any other provider. Google mobility data measure, on the daily basis, spatial and temporal changes in mobility across Poland in six areas: residential areas; supermarkets, grocery shops, and pharmacies; workplaces; retail and recreational areas; transit stations (subway, bus, and train stations); and parks, and compare this changes relative to baseline day before the pandemic outbreak.

As the website www.ourworldindata.org offers visual presentation (maps and graphs) based on Google data that shows how mobility patterns have changed throughout the pandemic for different locations such as regions and countries, we used this source to generate graphs for selected time perspectives. Baseline days represent typical values for specific days of the week, given as median values over the fiveweek period from January 3rd to February 6th 2020. Google note that comparing places across regions or countries should be avoided because there may be local differences in categories which could be misleading. Therefore we focused our analysis on Poland case only and on selected dates, which will be discussed further in details. We also resigned from comparing regions or powiats, although available in Google datasets, they would not be corresponding with the size criterion of the residential place that we took for analysis in survey research.

Table 1. Correlations between the size of the residential place (independent variable) and selected dependent variables on spatial mobility

\begin{tabular}{|l|c|c|}
\hline \multicolumn{1}{|c|}{ Dependent variable } & $\chi^{2}$ test & $\begin{array}{c}\text { Pearson correlation } \\
\text { coefficient }\end{array}$ \\
\hline Leaving the house only in the most needed matters & 0.018 & 0.58 \\
Doing occasionally some essential grocery shopping & 0.060 & 0.53 \\
Going out for a walk in neighbourhood & 0.000 & 0.46 \\
Going out primarily to work & 0.000 & -0.79 \\
Going out with child/pet everyday & 0.000 & -0.92 \\
Doing sports outside (running, cycling etc) & 0.000 & -0.59 \\
Going out for a walk to public places (parks, beaches, boulevard etc.) & 0.016 & -0.51 \\
Meeting regularly with friends & 0.007 & -0.54 \\
Going regularly to church & 0.000 & -0.74 \\
\hline
\end{tabular}

*The level of significance: $\alpha=0.05$ 
The general number of visitors in all locations, except for residential areas, has decreased significantly after first the week of March 2020 (Fig.4) due to the introduction of the state of epidemic in Poland on the 13th of March 2020 (Fig.1) and consecutive restrictions such as cancellation of mass events, closure of schools and universities, cultural institutions, limitations concerning number of passengers in public transport, and finally closure of parks and forests. It was only from the second half of April that the number of people staying in locations other than residential began to increase. Until April, only residential areas saw an increase in traffic, as it were usually the only places during this period where it was allowed to move around freely without breaking the rules. Between April and May 2020, while we were conducting survey research, spatial mobility returned to its baseline state (before the introduced restrictions) and even above only in relation to parks. On the other hand, the number of visitors in the residential area began to decline to the baseline in the end of May. More specifically, the possible causes of changes in spatial mobility in different types of areas are discussed below.
In retail and recreation areas that include places like restaurants, cafes, shopping centers, theme parks, museums, libraries, and movie theatres, the overall mobility decreased the most in early April and kept being low for almost a month. It was only in May that it slowly began to return to the pre-epidemic level, eventually reaching it in July. This situation resulted from the complete closure of shopping centers and cultural institutions, and then their gradual opening to a limited extent and with a limited number of customers. In April and May, customers also significantly limited their consumption needs and declared in the survey that they would only leave their apartments in the most necessary cases, making occasional purchases on average 1-2 times a week.

Our on-line survey did not include the exact question on the above mentioned recreational institutions, but more broadly referred to walks in public spaces, including promenades, boulevards, and parks. Only $5 \%$ of respondents indicated regular visits to these places in April and May, which is noticeable in the large decrease in mobility measured by the location of users in retail and recreation areas, as well as parks

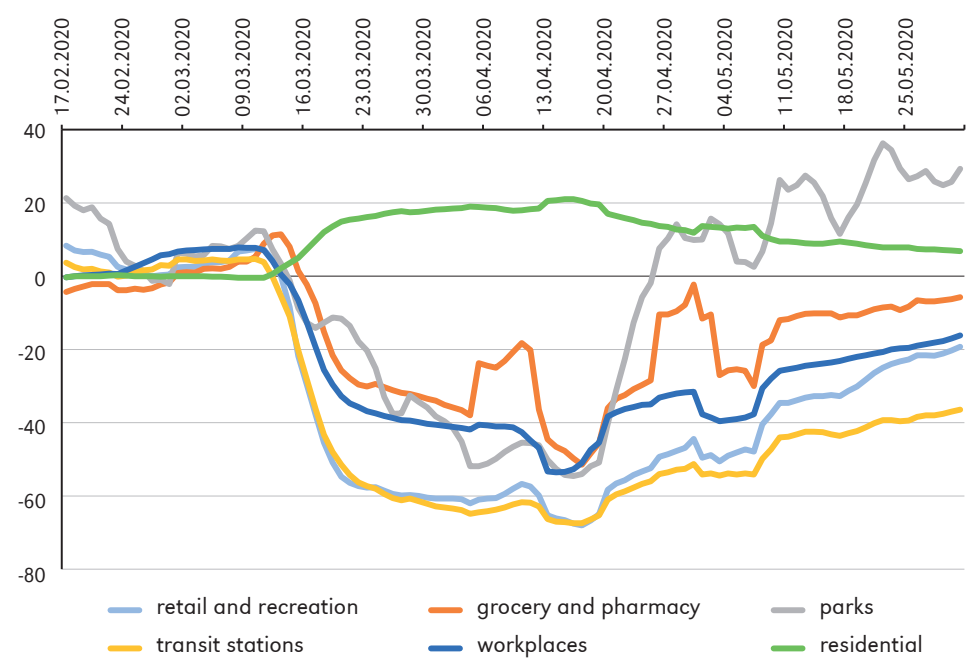

Figure 4. The change in number of visitors to categorised places compared to baseline days Source: own elaboration based on https://ourworldindata.org/covid-mobility-trends. 
and outdoor spaces. It should be mentioned here that at the beginning of April, a total ban on entering forests and parks was introduced, which lasted for almost two weeks. Such a restrictive solution was not commonly used in other countries. After the ban was lifted at the end of April, there has been a sharp increase in the number of people visiting green areas.

A slightly less deep and shorter decline than in trade occurred in the area of grocery and pharmacy stores, which includes places like grocery markets, food warehouses, farmers markets, specialty food shops, drug stores, and pharmacies. Despite the closure of shopping centers, many other shops continued to function, especially grocery stores and pharmacies. This aspect allowed for a faster return to the pre-epidemic state in this area, although some stores suspended their operation in shopping centers due to the unstable and uncertain situation. However, this does not exclude increased customer traffic in retail outlets located outside the shopping centres.

The other three areas, i.e. transit stations, workplaces and residential areas are closely related. Mobility in means of transport, especially at stations and interchange points, recorded the deepest drops and did not return to the pre-epidemic state by the end of August. This is partly the result of a significant proportion of employees switching to remote or mixed work, partly also due to the holiday period during the summer months. It is unlikely for transportation to return to its baseline state, as long as companies will operate in the remote mode, and unless educational institutions return to providing services in the traditional form. Also, when analysing the area of workplaces, mobility began to decline in mid-March, i.e. just after the schools were closed, and did not return to the pre-epidemic level. Only about $30 \%$ of the respondents in our survey regularly left the apartment primarily for purpose of work in April and May.

The last area refers to time spent in residential place in relation to the pre-epidemic time, not the number of visitors as in other categories. This is the only area where an increase in time spent in residential areas has been observed, particularly in April and May, which is understandable given the constraints on movement and access to various institutions, as well as the shift to remote work and on-line studying. The peak of the increase in time spent in the place of residence fell in Poland in mid-April, when the Easter holiday took place. After this event, the trend began to decline, which corresponded to the gradually lifted restrictions and the approaching holiday period.

\section{Discussion}

The preliminary results of the social survey on the perception of social distancing measure in the first weeks following the announcement of the epidemic in Poland, show that the respondents were highly disciplined in adapting to the rigors and restrictions introduced by national authorities and institutions responsible for public health. The positive response to public interventions in the form of actual spatial behaviours was observed also in Google spatial mobility data. This results correspond with other studies on behavioural responses to restrictions in early phase of the COVID-19 pandemic (Atchison et al., 2020), although the willingness and ability to adopt and follow the public health interventions depends on several factors.

The actual spatial mobility behaviours reflected by respondents in the study corresponded in general well with their declarations on supporting the necessary public interventions and obeying social distancing measures. Participants of the survey expressed significant change in their spatial everyday activities by limiting them when it was possible (compare with Weill et al., 2020). Those with better economic situations were more often able to work remotely and reduce their travels and mobility behaviours to necessary situations such as shopping or visiting pharmacy. The financial situation 
of respondents had similar effects on their spatial behaviours as the level of education. Participants with higher level of education did not need to leave their homes for professional reasons as often as respondents with lower educational level (Atchison et al., 2020). They could continue working from home and isolate at least from other workers which was not the option for all professions more dependent on traditional way of labour and with direct contact with the clients.

In terms of age, the most significant change in spatial behaviors concerned professionally active people. It was professional activity correlated with age group that was mainly responsible for the possibility of limiting leaving the apartment. Younger respondents were also more likely to engage in physical activity outside their home (Nguyen et al., 2020), and also spent time outside because of their children. In the case of the oldest respondents, a greater limitation of spatial behaviours was observed, which was mainly related to higher level of fear for their own health among this age category. Due to gender, there were also some differences in spatial mobility patterns. Women were more prone to social isolation and staying at home, although on the other hand, they were more dependent on daily duties, such as shopping. Men, on the contrary, were more often spatially mobile due to their professional work, and mainly the group that could not work remotely.

The size of the place of residence was an important factor differentiating the spatial behaviour and mobility of the respondents. Spatial mobility was less often limiting by inhabitants from rural areas and the smallest towns, where the size of the population, but also the population density is clearly lower. The respondents living in the largest and the most dense cities were also the most willing to social isolation and staying in their place of residence, which is confirmed by other studies (Arimura et al., 2020). The inhabitants of medium-sized towns and cities clearly more often undertook spatial behaviours due to work, which would indicate the specificity of local labour markets and less frequent possibility of switching to a remote work.

\section{Conclusions}

In the absence of a medical cure for the new coronavirus, policymakers and public health officials must resort to non-medical behavioural interventions. Lifting the national lockdown requires citizens to support and adhere to policy measures that contain the spread of the virus as social and economic activity gradually resumes. Given the difficulties in enforcing such legislation, future measures need to be both well-designed and well communicated. The more people are willing to voluntarily abide by the restrictive policies (Reluga, 2010), the less enforcement and supervision will be needed to achieve a high level of execution. For this, people's perceptions and attitudes should be taken into account in the design and implementation of the policy.

We are aware that the effect of spatial mobility drop during first weeks of pandemic in Poland was partially induced by governments actions, such as school or public spaces closures and state of epidemic emergency declarations, and encouraged individuals to adopt social distancing measures. An evaluation on how exactly these public health mitigation policies affect social distancing behaviours and the level of new infections is beyond the scope of this paper. It is also worth to notice that knowledge about the pandemic, applicable restrictions and related spatial behaviours have changed a lot from March 2020 and that we should not extrapolate our findings to subsequent stages of the pandemic.

Information on changes in spatial mobility and social reaction to the introduction of social distancing restrictions in epidemic conditions may constitute significant knowledge for public authorities regarding the implementation of specific solutions and analysing their effects (see also Zhou et al., 2020). The social survey research and quantitative analyses of mobility data discussed 
in this article indicate certain trends, but it seems to be too early for unambiguous conclusions. Despite the limitations in representativeness of the investigated sample, we find the results to be consistent and informative. However, interview-based follow-up research would be essential to examine knowledge, perception, and practice levels among Polish residents in the following months after the first lockdown period (March-April 2020). This would allow to compare whether the population consent to introduced restrictions in the beginning of the pandemic have changed during the time.

\section{Acknowledgements}

The authors gratefully acknowledge the reviewers' constructive comments on an earlier version of the paper. We also express our gratitude towards all those who took part in the survey and agreed to participate in the second wave of this study. We also would like to thank our colleagues for their feedback and scientifical support, particularly to professor Iwona Sagan and dr Maja Grabkowska from Institute of Geography at the University of Gdańsk, as well to Aleksandra Macul and Jakub Jan Rojek, from students' science club in Medical University of Gdańsk.

Editors' note:

Unless otherwise stated, the sources of tables and figures are the authors', on the basis of their own research.

\section{References}

Agüero, F., Adell, M.N., Perez Gimenez, A., Lopez Medina, M.J., Garcia Continente, X. (2011). Adoption of preventive measures during and after the 2009 influenza A (H1N1) virus pandemic peak in Spain. Preventive Medicine, 53(3), 203-206. https://doi.org/10.1016/j.ypmed.2011.06.018

Aloi, A., Alonso, B., Benavente, J., Cordera, R., Echaniz, E., Gonzalez, F., Ladisa, C., Lezama-Romanelli, R., Lopez-Parra, A., Mazzei, V., Perrucci, L., Prieto-Quintana, D., Rodriguez, A., Sanudo, R. (2020). Effects on the COVID-19 lockdown on urban mobility: empirical evidence from the city of Santander (Spain). Sustainability, 12, 3870; https://doi.org/10.390/su12093870

Arimura, M., Vinh Ha, T., Okumura, K., Asada, T. (2020). Changes in urban mobility in Saporro city, Japan due to the COVID-19 emergency declarations. Transportation Research Interdisciplinary Perspectives, 7. https://doi.org/10.1016/j.trip.2020.100212

Atchison, C.J., Bowman, L., Vrinten, C., Redd, R., Pristera, P., Eaton, J.W., Ward, H. (2020). Perceptions and behavioural responses of the general public during the COVID-19 pandemic: a cross-sectional survey of UK adults. medRxiv. https://doi.org/10.1101/2020.04.01.20050039

Bański, J. (2009). Odrębność obszaru podmiejskiego w kontinuum miejsko-wiejskim, Czasopismo Geograficzne, 80(4), 210-228.

Bernard, J. (1993). Espoirs et sagesse de la médicine. Paris: Éditions Odile Jacob.

Ciancio, A., Kampfen, F., Kohler, I.V., Bennett, D., de Bruin, W.B., Darling, J., Kapteyn, A., Maurer, J., Kohler, H. (2020). Know your epidemic, know your response: Early perceptions of COVID-19 and selfreported social distancing in the United States. PLoS ONE, 15(9), e0238341. https://doi.org/10.1371/journal.pone.0238341

Drake, T.M., Docherty, A.B., Weiser, T.G., Yule, S., Sheikh, A., Harrison, E.M. (2020). The effects of physical distancing on population mobility during the COVID-19 pandemic in the UK. The Lancet Digital Health, 2(8), e385-e387. https://doi.org/10.1016/S2589-7500(20)30134-5

Engle, S., Stromme, J., Zhou, A. (2020). Staying at home: Mobility effects of COVID-19. Working paper. https://doi.org/10.2139/ssrn.3565703 
Falkowski, J., Brodowski, P. (2008). Ocena kontinuum miejsko-wiejskiego obszarów metropolitarnych Polski metoda potencjału społeczno-gospodarczego, Studia Obszarów Wiejskich, 13, 11-35.

Google Mobility Trends: How has the pandemic changed the movement of people around the world? (2020). Our World in Data. https://ourworldindata.org/covid-mobility-trends [05 February 2021]

Grad, J. (2010). Współczesny sens regionalizmu, Sensus Historicae, 1(1), 51-68.

Hays, J.N. (2005). Epidemics and pandemics: Their impacts on human history. Santa Barbara: ABC-CLIO.

Honigsbaum, M. (2013). "An inexpressible dread": Psychoses of influenza at fin-de-siècle. The Lancet, 381(9871), 988-989. https://doi.org/10.1016/S0140-6736(13)60701-1

Huang, Ch., Wang, Y., Li, X., Ren, L., Zhao, J., Hu, Y., Zhang, L., Fan, G., Xu, J., Gu, X., Cheng, Z., Yu, T., Xia, J., Wei, Y., Wu, W., Xie, X., ... Cao, B. (2020). Clinical features of patients infected with 2019 novel coronavirus in Wuhan, China. The Lancet, 395(10223), 497-506.

https://doi.org/10.1016/S0140-6736(20)30183-5

Huang, H.M. (2006). Do print and Web surveys provide the same results? Computers in Human Behavior, 22(3), 334-350. https://doi.org/10.1016/j.chb.2004.09.012

Huang, Y., Zhao, N. (2020). Generalized anxiety disorder, depressive symptoms and sleep quality during COVID-19 outbreak in China: A web-based cross-sectional survey. Psychiatry Research, 288, 112954. https://doi.org/10.1016/j.psychres.2020.112954

Kaplan, H., Trumble, B.C., Stieglitz, J., Mendez Mamany, R., Gutierrez Cayuba, M., Maito Moye, L., Alami, S., Kraft, T., Gutierrez, R.Q., Adrian, J.C., Thompson, R.C., Thomas, G.S., Michalik, D.E., Rodriguez, D.E., Gurven, M.D. (2020). Voluntary collective isolation as a best response to COVID-19 for indigenous populations? A case study and protocol from the Bolivian Amazon. The Lancet, 395(10238), 1727-1734. https://doi.org/10.1016/S0140-6736(20)31104-1

Kulesza, M. (2014). Rozważania na temat regionu geograficzno-historycznego. Studia z Geografii Politycznej i Historycznej, 3, 27-48.

Luo, M., Guo, L., Yu, M., Jiang, W., Wang, H. (2020). The psychological and mental impact of coronavirus disease 2019 (COVID-19) on medical staff and general public - A systematic review and meta-analysis. Psychiatry Research, 291, 113190. https://doi.org/10.1016/j.psychres.2020.113190

McCaa, R. (1995). Spanish and Nahuatl views on smallpox and demographic catastrophe in the conquest of Mexico. Journal of Interdisciplinay History, 25(3), 397-431. https://doi.org/10.2307/205693

Medicover. (2020). Pandemia koronawirusa na świecie i w Polsce - kalendarium. Medicover. (2020). https://www.medicover.pl/o-zdrowiu/pandemia-koronawirusa-na-swiecie-i-w-polsce-kalendarium,7252,n,192

Meier, M. (2016). The 'Justinianic Plague': the economic consequences of the pandemic in the eastern Roman empire and its cultural and religious effects. Early Mediewal Europe, 24(3), 267-292. https://doi.org/10.1111/emed.12152

Meier, K., Glatz, T., Guijt, M.C., Piccininni, M., van der Meulen, M., Atmar, K. (2020). Public perspectives on protective measures during the COVID-19 pandemic in the Netherlands, Germany and Italy: A survey study. PLoS ONE, 15(8), e0236917. https://doi.org/10.1371/journal.pone.0236917

Moghanibashi-Mansourieh, A. (2020). Assessing the anxiety level of Iranian general population during COVID-19 outbreak. Asian Journal of Psychiatry, 51, 102076. https://doi.org/10.1016/j.ajp.2020.102076

Mordechai, L., Eisenberg, M., Newfield, T.P., Izdebski, A., Kay, J.E., Poinar, H. (2019). The Justinianic Plague: An inconsequential pandemic?. PNAS, 116(51), 25546-25554.

https://doi.org/10.1073/pnas.1903797116

Nguyen, D.V., Pham, G.H., Nguyen, D.N. (2020). Impact of the COVID-19 pandemic on perceptions and behaviors of university students in Vietnam. Data in Brief, 31, 105880.

https://doi.org/10.1016/j.dib.2020.105880

Nuland, S.B. (1993). How we die: Reflections on life's final chapter. Toronto: Random House of Kanada. 
Ozamiz-Etxebarria, N., Dosil-Santamaria, M., Picaza-Gorrochategui, M., Idoiaga-Mondragon, N. (2020). Stress, anxiety, and depression levels in the initial stage of the COVID-19 outbreak in a population sample in the northern Spain. Cadernos de Saúde Pública, 36(4), e00054020. https://doi.org/10.1590/0102-311X00054020

Pinkas, J., Jankowski, M., Szumowski, Ł., Lusawa, A., Zgliczyński, W.S., Raciborski, F., Wierzba, W., Gujski, M. (2020). Public health interventions to mitigate early spread of SARS-CoV-2 in Poland. Medical Science Monitor: International Medical Journal of Experimental and Clinical Research, 26, e924730. https://doi.org/10.12659/MSM.924730

Raciborski, F., Pinkas, J., Jankowski, M., Sierpiński, R., Zgliczyński, W.S., Szumowski, Ł., Rakocy, K., Wierzba, W., Gujski, M. (2020). Dynamics of the coronavirus disease 2019 outbreak in Poland: an epidemiological analysis of the first 2 months of the epidemic. Polish Archives of Internal Medicine, 130(7-8), 615-621. https://doi.org/10.20452/pamw.15430

Reluga, T.C. (2010). Game theory of social distancing in response to an epidemic. PLoS Computational Biology, 6(5), e1000793. https://doi.org/10.1371/journal.pcbi.1000793

Ruffié, J., Sournia, J.C. (1999). Les épidemiés dans I'historie de I'home. Paris: Flammarion.

Sabat, I., Neuman- Böhme, S., Varghese,. N.E., Barros, P.P., Brouwer, W., Exel van, J., Schreyögg, J., Stargardt, T. (2020). United but divided: Policy responses and people's perceptions in the EU during the COVID-19 outbreak. Health Policy, 124(9), 909-918. https://doi.org/10.1016/j.healthpol.2020.06.009

Santamaria, C., Sermi, F., Spyratos, S., lacus, S.M., Annunziato, A., Tarch, D., Vespe, M. (2020). Measuring the impact of COVID-19 confinement measures on human mobility using mobile positioning data. A European regional analysis. Safety Science, 132, 104925. https://doi.org/10.1016/j.ssci.2020.104925

Siemiński, J.L. (2010). Kontinuum miejsko-wiejskie i niektóre jego problemy infrastrukturalne. Infrastruktura i Ekologia Terenów Wiejskich, 2/2010, 215-228.

Siuda, P. (2010). Prowadzenie badań w Internecie - podstawowe problemy etyczne, Ruch Prawniczy, Ekonomiczny i Socjologiczny, 72(4), 187-202.

Sznajderman, M. (1994). Zaraza: Mitologia dżumy, cholery i AIDS. Warszawa: Wydawnictwo Naukowe Semper.

Śleszyński, P. (2013). Delimitacja Miejskich Obszarów Funkcjonalnych stolic województw. Przegląd Geograficzny, 85(2), 173-197. https://doi.org/10.7163/przg.2013.2.2

Śleszyński, P. (2015). Problemy delimitacji miejskich obszarów funkcjonalnych w Polsce. Rozwój Regionalny i Polityka Regionalna, 29, 37-53. https://doi.org/10.14746/rrpr.2015.29.04

Śleszyński, P. (2016). Naukowe podstawy i praktyczne problemy klasyfikacji i delimitacji obszarów metropolitarnych. Metropolitan. Przeglad Naukowy, 2(6), 14-25.

Tarkowski, M., Puzdrakiewicz, K., Jaczewska, J., Połom, M. (2020). COVID-19 lockdown in Poland changes in regional and local mobility patterns based on Google Maps data. Prace Komisji Geografii Komunikacji PTG, 23(2), 46-55. https://doi.org/10.4467/2543859XPKG.20.007.12105

Ustawa z dnia 2 marca 2020 r. o szczególnych rozwiqzaniach zwiqzanych z zapobieganiem, przeciwdziałaniem i zwalczaniem COVID-19, innych chorób zakaźnych oraz wywołanych nimi sytuacji kryzysowych, 2020, Dziennik Ustaw 2020 poz. 374.

Weill, J., Stigler, M., Deschenes, O., Springborn, M. (2020). Social distancing responses to COVID-19 emergency declarations strongly differentiated by income. PNAS, 117(33), 19658-19660. https://doi.org/10.1073/pnas.2009412117

Welford, M. (2018). The mediewal Black Death arrives in Europe. In M. Welford (Ed.), Geographies of plague pandemics. The spatial-temporal behavior of plague to the modern day (pp. 36-72). London: Routledge. https://doi.org/10.4324/9781315307435-4

WHO Director-General's opening remarks at the media briefing on COVID-19 - 11 March 2020. (2020). World Health Organization. https://www.who.int/dg/speeches/detail/who-director-general-s-openingremarks-at-the-media-briefing-on-covid-19---11-march-2020 
Yadav, P., Bhattacharjee, A. (2020). Impact of COVID-19 on mobility in India: A spatial approach. Radical Statistics, 126, 75-90. https://www.researchgate.net/publication/342764203

Zhou, Y., Xu, R., Hu, D., Yue, Y., Li, Q., Xia, J. (2020). Effects of human mobility restrictions on the spread of COVID-19 in Shenzhen, China: A modelling study using mobile phone data. The Lancet Digital Health, 2(8), e417-e424. https://doi.org/10.1016/S2589-7500(20)30165-5 